Original article

\title{
3D printed tissue and organ using additive manufacturing: An overview
}

\author{
Mohd Javaid*, Abid Haleem \\ Department of Mechanical Engineering, Jamia Millia Islamia, New Delhi, India
}

\section{A R T I C L E I N F O}

\section{Keywords:}

3D printing

Additive manufacturing (AM)

Organ printing

Scaffold

Tissue printing

\begin{abstract}
A B S T R A C T
Background: Research papers on Additive Manufacturing (AM)/3D printing in tissue/organ printing are studied to understand its capability for tissue and organ printing with and new advancement in the medical field. Aim of the research: To study and discuss the advantages and limitations of AM when used for printing of customised scaffold, tissue and organ, which are a challenge to the medical field.

Materials and methods: This literature-based study understands the creation of innovation in the medical field and its different areas to address upcoming challenges. Thus, relevant research papers from the Scopus database are identified and purposefully analysed.

Result: Studied the main components of additive manufacturing as required for tissue and organ printing and process used to create tissue/organ by using this technology. We have further identified different materials based requirements for tissue and organ printing and how this technology can fulfil this requirement to save the life of the patient. Finally, this paper identifies eight significant advancements of AM in the medical field with a brief description and limitations when additive manufacturing is used for tissue and organ printing.

Conclusion: In the current scenario, tissue engineering and cell therapy employ an innovative approach to reduce the mortality rate. However, the main challenge for this is customisation, which is somewhat taken up by AM technologies. This technology has already addressed different challenges in the medical field. For tissue and organ printing, this technique seems better as compared to 2D conventional cell technique. With the help of scanned data, 3D printing allows us to create intricate internal structures. Thus, it can be used to develop bone tissues, which are required for clinical applications towards the treatment of bone defects. It also plays an outstanding role in cardiac masses, heart disease, physiology, electrophysiology, tested for diagnosis and better treatment of valvular heart disease. Doctors and surgeon easily understand the aortic valve of the patient. It improves post-surgery, blood flow and helps proper selection of devices including stents. AM is to take up the challenge for the development of artificial bone with biomechanical properties as similar to bone. It uses the material in the form of powder, wire and ceramic. It has promising applications to print liver tissue and liver cell and fulfils the requirement of customisation in different fields.
\end{abstract}

\section{Introduction}

A large number of patients die due to the shortage of organs like kidney, heart, liver, etc., but these organs are highly customised, and here, Additive Manufacturing (AM) has extensive utility. ${ }^{1-3}$ In the medical field, AM technology is an innovative approach used for the production of tissues and human organs. It is applicable for highly complex native organs which can be transplanted in the human body in the operating room. New biomaterials are used to fabricate scaffolds, tissue and organs, and they show a better biocompatibility, ${ }^{4,5}$ but we need to research them thoroughly before making patient-specific applications. In the medical field, AM is rapidly adopted due to its patient-specific implants, tissue, scaffolds and organs. This technology can print materials having excellent biodegradable and mechanical properties. $^{6}$

Additive manufacturing becomes cheaper and efficient when used for specific applications and is the best method of creating a specific prototype. AM creates a product from computer-aided design (CAD) file, which is usually in standard triangulate language (STL) format. This format is imported in the printer to create an object, layer by layer. Here, the printing time depends on layer thickness and the size of the object. Complex shape object takes a long time for printing. Support

\footnotetext{
* Corresponding author.

E-mail addresses: mjavaid@jmi.ac.in (M. Javaid), ahaleem@jmi.ac.in (A. Haleem).

https://scholar.google.co.in/citations?user =rfyiwvsAAAAJ\&hl=en (M. Javaid), https://scholar.google.co.in/citations? user $=4047148$ AAAAJ\&hl $=$ en $($ A. Haleem)
} 
Table 1

Components of AM for tissue and organ printing.

\begin{tabular}{|c|c|c|c|}
\hline S No & Main Components & Description & References \\
\hline 1 & Hardware & $\begin{array}{l}\text { - AM consists of hardware, and its hardware are a 3D printer, 4D printer, 5D printer } \\
\text { and Scanner } \\
\text { - 3D printing technology is used as hardware to print any customised medical part } \\
\text { - There are different types of processes and technologies of 3D printing; each 3D } \\
\text { printing technologies has its advantages and limitations } \\
\text { - The leading 3D printing technologies are used for the tissue, and organ printings are } \\
\text { extrusion, inkjet and laser-assisted technology }\end{array}$ & $\begin{array}{l}\text { Derby, } 2012^{20} \text {; Bose et al., } 2013^{21} \text {; Singh et al., } 2017^{22} \text {; } \\
\text { Maiullari et al., } 2018^{23}\end{array}$ \\
\hline 2 & Software & $\begin{array}{l}\text { - 3D designing software provides an enhanced capability for the design and } \\
\text { development of product } \\
\text { - There are different types of software available for the designing such as Solidworks, } \\
\text { Mimics, Ansys, Fusion 360, Auto CAD, 3DS Max, Rhino, Inventor and Moment of } \\
\text { Inspiration (MoI) 3D } \\
\text { - Software plays an essential role in the creation of design, modification, testing, } \\
\text { analysis and reverse engineering } \\
\text { - 3D design software can precisely create any 3D surface model of any medical, } \\
\text { industrial, dentistry, automobile and architecture product }\end{array}$ & $\begin{array}{l}\text { Gómez-Ciriza et al., } 2015^{24} \text {; Pati and Cho, } 2017^{25} \text {; } \\
\text { Laschke and Menger, } 2017^{26} \text {; Haleem and Javaid, } 2019^{27}\end{array}$ \\
\hline 3 & Bioink & $\begin{array}{l}\text { - Bioink having living cells are capable of recreating the desired shape } \\
\text { - The slurry of specific cells are loaded in the printing head which is moved through } \\
\text { digital control to recreate the desired object } \\
\text { Bioinks can be used in 3D printer technology to produce complex tissue model which } \\
\text { have extracellular matrix environment } \\
\text { - Bioink can deposit filament while using the process of additive manufacturing } \\
\text { gelatin, alginates, chitosan, and hyaluronic acids }\end{array}$ & $\begin{array}{l}\text { Stanton et al., } 2015^{28} \text {; Ligon et al., } 2017^{29} \text {; Onget al., } \\
2017^{30}\end{array}$ \\
\hline 4 & Biomaterial & $\begin{array}{l}\text { Extensive investment is made in medicine for the development of new biomaterial } \\
\text { which encompasses elements of biological, medicine, tissue engineering, chemistry } \\
\text { and material science } \\
\text { - Biomaterial having a biological system which easily interacts with the biological } \\
\text { system } \\
\text { - Used in the medical field for treatment and replacement/repair of tissue of the body } \\
\text { - A biomaterial is used for heart valves, joint replacement, bone cement, medical } \\
\text { implants, skin repair devices, stents, surgical mesh, vascular graft etc }\end{array}$ & $\begin{array}{l}\text { Butscher et al., } 2013^{31} \text {; Usprech et al., } 2017^{32} \text {; } \\
\text { Jammalamada and Tappa, } 2018^{33}\end{array}$ \\
\hline
\end{tabular}

Table 2

Processes used to create tissue/organ using additive manufacturing.

\begin{tabular}{|c|c|c|c|}
\hline S No & Process Steps & Description & References \\
\hline 1 & CAD design & $\begin{array}{l}\text { - Create a 3D digital model of the scaffold, tissue and organ using different } \\
\text { scanning technologies like CT, MRI, 3D scanner etc. } \\
\text { - 3D CAD data is exported to the desired printer in.STL format } \\
\text { - These scanning technologies easily capture exact data of the patient as per } \\
\text { requirement }\end{array}$ & $\begin{array}{l}\text { Yoo et al., } 2014^{36} \text {; Ripley et al., } 2016^{37} \text {; Ackland } \\
\text { et al., } 2017^{38}\end{array}$ \\
\hline 2 & The input of specific Biomaterial & $\begin{array}{l}\text { - A specific biomaterial is used to fabricate a biocompatible medical part } \\
\text { Bioactive drugs, protein and cells are used as inputs for 3D printing } \\
\text { technology } \\
\text { - There are wide biomaterial variety is used, these include ceramics, metals, } \\
\text { composites and polymers }\end{array}$ & $\begin{array}{l}\text { Schieker et al., } 2006^{39} \text {; Tappa and } \\
\text { Jammalamadaka, } 2018^{40}\end{array}$ \\
\hline 3 & $\begin{array}{l}\text { 3D printing of scaffold tissue/ } \\
\text { organ }\end{array}$ & $\begin{array}{l}\text { - After preparation of CAD data of the individual patient and specified } \\
\text { biomaterial input, 3D physical scaffold tissue/organs are manufactured layer } \\
\text { by layer } \\
\text { - Encouraging results while using AM applications in developing specific 3D } \\
\text { scaffolds for tissue engineering, manufacturing of customised implants, drug } \\
\text { delivery devices, prosthetics and regenerative medicine } \\
\text { - 3D printing technology can enhance its printability with the combination of } \\
\text { polymers and ceramics }\end{array}$ & $\begin{array}{l}\text { Yang et al., } 2008^{41} \text {; Do et al., } 2015^{42} \text {; O'Brien et al., } \\
2015^{43} \text {; An et al.,2015 } 5^{44} \text {; Qiu et al., } 2018^{45}\end{array}$ \\
\hline 4 & Cell Seeding & $\begin{array}{l}\text { - 3D printing is an efficient method of supporting scaffolds with seeding cell } \\
\text { - These cell help to repair tissue and enhance the functions in the body } \\
\text { - This technology quickly helps to develop and fabricate self-assembled tissue } \\
\text { by seeding cells }\end{array}$ & $\begin{array}{l}\text { Bertassoni et al., } 2014^{46} \text {; Csobonyeiova et al., } \\
2015^{47} \text {; Gao et al., } 2017^{48}\end{array}$ \\
\hline 5 & $\begin{array}{l}\text { Implementation of tissue/organ } \\
\text { in the patient body }\end{array}$ & $\begin{array}{l}\text { - Medically required parts printed by this technology are implanted into the } \\
\text { body of the patient } \\
\text { - Different types of tissue are made with particular cells; these include muscle } \\
\text { tissue, Epithelial Tissue, Nervous Tissue etc. } \\
\text { - These make an excellent proactive cover of the body with attractive skin }\end{array}$ & $\begin{array}{l}\text { Li et al., } 2014^{49} \text {; Bishop et al., } 2017^{50} \text {; Kiraly and } \\
\text { Khalifa, } 2018^{51}\end{array}$ \\
\hline
\end{tabular}

material if used for certain conditions is removed after the completion of the object printing. AM produce specialized tools, detailed parts and related customised medical devices. This technology is cheaper to provide better business options. ${ }^{7-9}$

Additive manufacturing is an innovative technology which manufactures objects/parts layer by layer deposition of material. It employs different types of 3D printing technologies to fabricate tissues and organs using technologies like extrusion and inkjet. Fused deposits modelling (FDM) based 3D printer is used commonly which are lower in cost and has moderate flexibility. It uses plastic/other filaments 
Table 3

Different requirements of materials for tissue and organ printing.

\begin{tabular}{|c|c|c|c|}
\hline S No & Requirement & Description & References \\
\hline 1 & Biocompatibility & $\begin{array}{l}\text { - This is the performance of non-biological materials when implanted in the } \\
\text { patient body having no biological tissue reaction } \\
\text { - It must have excellent biological properties and appropriate for clinical use } \\
\text { - The biocompatible material can perform appropriate response in the } \\
\text { human body during a specific situation } \\
\text { - The biomaterial can perform the desired function of medical therapy and } \\
\text { appropriate for cellular/tissue response }\end{array}$ & $\begin{array}{l}\text { Wang et al., } 2007^{53} \text {; Zhang et al.,2014 }{ }^{54} \text {; Luo et al., } \\
2015^{55} \text {; Zhang et al., } 2016^{56}\end{array}$ \\
\hline 2 & $\begin{array}{l}\text { Good \& appropriate mechanical } \\
\text { properties }\end{array}$ & $\begin{array}{l}\text { - Implants like a bone for a patient must have desired mechanical properties } \\
\text { - It assists a whole load of patient body and adjusts bone tissue } \\
\text { - It must be harmless which allows functioning as a natural substitute } \\
\text { - The material should possess mechanical stability for the reliability of the } \\
\text { graft } \\
\text { - The material must be created under the consideration of Hardness, } \\
\text { Fatigue, Fracture strength and toughness }\end{array}$ & $\begin{array}{l}\text { Wang et al., } 2016^{57} \text {; Mironov et al., } 2017^{58} \text {; Hangge } \\
\text { et al., } 2018^{59}\end{array}$ \\
\hline 3 & Porosity & $\begin{array}{l}\text { - 3D printed medical implants must have high porosity having cell } \\
\text { attachment } \\
\text { - It should have an excellent degree of connectivity between the pores } \\
\text { Porous materials show the ability to interact with biological molecules and } \\
\text { ions throughout the bulk } \\
\text { - Porosity promotes tissue growth which employed for various part of the } \\
\text { body like skin, cartilage, bone, vasculature etc } \\
\text { - Porosity allows specific interaction with target molecules of available } \\
\text { surface area }\end{array}$ & $\begin{array}{l}\text { Seitz et al., } 2005^{60} \text {; Lee et al., } 2008^{61} \text {; Zhou et al., } \\
2008^{62}\end{array}$ \\
\hline 4 & Biological structure & $\begin{array}{l}\text { - It should have a biological structure which can survive tissue and other } \\
\text { functions } \\
\text { - It varies from person to person as per the requirements } \\
\text { - The biological structure must deal with the molecular structure of } \\
\text { biological macromolecules and cells } \\
\text { - It has to cater to the intricate and exquisite choreography of life }\end{array}$ & $\begin{array}{l}\text { Cohen et al., } 2010^{63} \text {; Bergmann et al., } 2010^{64} \text {; Kang } \\
\text { et al., } 2016^{65}\end{array}$ \\
\hline
\end{tabular}

which are passed through a hot nozzle. This material is then deposited layer by layer on the print bed - these numbers of a required layer added to form a part. There are different types of materials used in FDM like thermoplastic, metal, wood, pastes, chocolates etc. In this process, the material is extruded through the nozzle, which is just passed its glass transition temperature. This technology uses two types of materials; one is modelling material which is used to create a finished object. Another is support material which supports the object during the printing of part. The main application of support material is to manufacture complicated design part without any defect precisely. ${ }^{10,11}$ These materials are in the plastic thread form, which fed through an extrusion nozzle. Nozzles are controlled through a computer in $\mathrm{X}, \mathrm{Y}$ and $\mathrm{Z}$ coordinates and follow the printing path. It moves in built form vertically and horizontally as per the cross-section of an object. Once one layer is completed, the base is lowered as per layer thickness and makes room for the next layer. This process is repeated continuously until completing the object. ${ }^{12,13}$

Another AM technology used for tissue and organ printing is inkjet technology. It uses a print head which contains different cell that allows producing multicellular organ/tissue and is used for the production of complex organ-regenerative scaffolds like liver tissue, aortic valves, cartilage and bone and is now getting popular. ${ }^{14}$

\section{Research questions}

AM can help produce complex tissue engineering scaffolds and organs as per patient-specific anatomical data. It is applicable for the preparation of tooling and devices moulds. This tissue printing is an innovative technique to fulfil the increasing demand for organ transplant. ${ }^{15-17}$ AM provides the right quality product with the input of good quality material. It is used to manufacture customised and complex enduse products without the requirement of any tooling. This study tries to address different research questions. It tries to identify the research status on "AM in tissue and organ printing" and "3D printing in tissue and organ printing" through a systematic study of the main components of AM for tissue and organ printing. Further, we need to identify processes used to print organ and tissue using AM and also the different requirements of materials for tissue and organ printing. Thus, through this review based research, we need to identify innovative applications of AM in the medical field and undertake a study of different limitations of AM, when used for tissue and organ printing.

\section{Research status}

Research on additive manufacturing is continuously increasing in the area of tissue and organ printing. Here, we have identified research status on "Additive manufacturing in tissue and organ printing" and "3D printing in tissue and organ printing" from the Scopus database and discussed in the following sub-sections.

\subsection{Research status on additive manufacturing in tissue printing}

Taking data from Scopus by search keywords as "additive manufacturing" "tissue", a total of 1174 research article published so far. The first article got published in 2004 and published only one research article in this year. After that, in 2006, two research articles were published. Again there was one year gap of publication in the research article. After that, there was continuously paper published in the year 2008. In year 2008 (2), 2009 (1), 2010 (15), 2011 (17), 2012 (28), 2013 (53), 2014 (80), 2015 (114), 2016 (176), 2017 (215), 2018 (239) articles was published. In this year, up to October 2019, 237 research articles are published so far.

Different sources and journal published research articles in this newly emerging area by the applications of additive manufacturing. Here, we show top five journals, and these include Biofabrication (47), Acta Biomaterialia (37), Journal of the Mechanical Behavior of Biomedical Materials (27), Materials Science and Engineering C (27) and Materials journal published 25 research articles.

In country-wise contribution, the United States has a maximum contribution of $22 \%$, among all the countries. Whereas, China ( $8 \%$ ), Germany (7\%), United Kingdom (7\%), Italy (6\%), Australia (5\%), Netherlands (4\%) and other countries also contribute $41 \%$. 
Table 4

Different advancement of additive manufacturing in the medical field.

\begin{tabular}{|c|c|c|c|}
\hline S. No & Advancements & Description & References \\
\hline 1 & Human Organ & $\begin{array}{l}\text { - Researchers and scientist print kidney cell and sheets of cardiac tissue which } \\
\text { works like an original } \\
\text { - 3D printed organs are used to provide similar functions as original } \\
\text { - Used for unique specific organs like main tissues of heart, nerves, blood vessels etc } \\
\text { - 3D printing used bioink to print tissue, human cells and livers to become more } \\
\text { reality } \\
\text { - Helpful for regenerative medicine for 3D printed organ and tissue for transplant } \\
\text { - Easily create a biodegradable scaffold, and by using bioink in 3D printing, it } \\
\text { creates an exact shape of organs with growing cell }\end{array}$ & $\begin{array}{l}\text { Murphy et al., } 2014^{69} \text {; Knowlton et al., } 2016^{70} \text {; Ji and } \\
\text { Guvendiren, } 2017^{71} \text {; Capel et al., } 2019^{72}\end{array}$ \\
\hline 2 & Cells printing & $\begin{array}{l}\text { - In the human body, cells have excellent regenerative properties which can help to } \\
\text { produce human tissues } \\
\text { - It can print tissue with cells which directly imparts in the patient body } \\
\text { - A scientist can print personalized 3D heart with human tissue and human cells } \\
\text { - 3D cell printing technology has excellent flexibility and potential to create } \\
\text { advancement in the medical field }\end{array}$ & $\begin{array}{l}\text { Cai et al., } 2005^{73} \text {; Huh et al., } 2011^{74} \text {; Kolesky et al., } \\
2014^{75} \text {; Zhao et al., } 2014^{76} \text {; Jang et al., } 2017^{77}\end{array}$ \\
\hline 3 & Printing of heart & $\begin{array}{l}\text { This technology can easily create a heart and different valves as per patient shape } \\
\text { and size } \\
\text { - It fabricates cardiac tissue like an original } \\
\text { - 3D printing can print heart and its customised parts with the help of bio-inks } \\
\text { using fatty tissue } \\
\text { - A scientist can print 3D heart using human tissue, blood vessels, ventricles, cells } \\
\text { and chambers }\end{array}$ & $\begin{array}{l}\text { Costello et al., } 2015^{78} \text {; Kolesky et al., } 2016^{79} \text {; Lau } \\
\text { et al., } 2018^{80}\end{array}$ \\
\hline 4 & Skin printing & $\begin{array}{l}\text { - This technology can be used for printing skin graft for the burn patient or skin } \\
\text { cancer patient } \\
\text { - It can be somewhat successfully implemented into the patient body without any } \\
\text { risk } \\
\text { - AM has the potential to print skin to save millions of lives } \\
\text { - This technology has promising applications for 3D printed human skin which } \\
\text { creates a natural structure of the skin to get the protection of the external } \\
\text { environment }\end{array}$ & Lee et al., $2014^{81}$; Takahashi and Okano, $2015^{82}$ \\
\hline 5 & Bone tissue engineering & $\begin{array}{l}\text { Bone tissue engineering consists of three elements, i.e. bone scaffolds, cells and } \\
\text { growth factors } \\
\text { - It can easily manufacture bone scaffolds which are essential for bone tissue } \\
\text { engineering } \\
\text { - AM technology meets the requirements of bone defects and trauma of the patient } \\
\text { - It provides biological properties with the growth of surrounding tissue } \\
\text { - AM is useful for scaffolds fabrication that proves ideal for tissue bone engineering } \\
\text { and with specific strength abilities } \\
\text { - In upcoming years, the ability of this technology is bound to increase due to its } \\
\text { ability of custom bone tissue engineering for patient and clinical need }\end{array}$ & $\begin{array}{l}\text { Xiong et al., } 2002^{83} \text {; Leukers et al., } 2005^{84} \text {; Mota et al., } \\
2016^{85}\end{array}$ \\
\hline 6 & $\begin{array}{l}\text { Printing of smart } \\
\text { material }\end{array}$ & $\begin{array}{l}\text { - Smart material has the capability of self-assembly and self-repairs to provide } \\
\text { multi-functionality in the medical field } \\
\text { - AM is also useable to print smart materials, and this technology is the extension of } \\
\text { 3D printing commonly known as 4D printing } \\
\text { - Smart materials provide shape-changing abilities over time and with the help of } \\
\text { temperature and pressure } \\
\text { - Used to manufacture Smart stent, smart medical devices, implants etc. which can } \\
\text { change shape as per the requirement of the patient }\end{array}$ & $\begin{array}{l}\text { Miao et al., } 2017^{86} \text {; Javaid and Haleem, } 2018^{87} \text {; } \\
\text { Piedade, 2019 }\end{array}$ \\
\hline 7 & Heart tissue & $\begin{array}{l}\text { - One of the main challenges of the heart tissue is to supply oxygen and nutrients } \\
\text { for heart tissue } \\
\text { - This technology correctly creates heart tissue to increase outcome and proper } \\
\text { function in the heart of the patient } \\
\text { - AM develops cardiac tissues to restore blood perfusion } \\
\text { - Heart tissue provides an option for a heart transplant for the cardiac patients }\end{array}$ & $\begin{array}{l}\text { Giannopoulos et al., } 2016^{90} \text {; Yoo et al., } 2016^{91} \text {; Qasim } \\
\text { et al., } 2019^{92}\end{array}$ \\
\hline 8 & Vascular channels & $\begin{array}{l}\text { - AM is available to design and development of vascular channel and hollow tubes } \\
\text { as per the required diameter } \\
\text { - This technology creates vascular channels with cells and biological matrices } \\
\text { - Used to construct larger perfusable channels to create innovation in the medical } \\
\text { field } \\
\text { - It seems to the best technology to fulfil challenges of complex vascularized tissue } \\
\text { fabrications }\end{array}$ & $\begin{array}{l}\text { Will et al., } 2008^{93} \text {; Zhou et al., } 2017^{94} \text {; Datta et al., } \\
2017^{95} \text {; Javaid and Haleem, } 2019^{96}\end{array}$ \\
\hline
\end{tabular}

In area wise contributions, the engineering field has a maximum contribution of $29 \%$. The other field provides materials Science (24\%), Biochemistry, Genetics and Molecular Biology (11\%), Chemical Engineering (8\%), Medicine (6\%), Physics and Astronomy (5\%), Computer Science (5\%) and 7\% contribution.

\subsection{Research status on additive manufacturing in organ printing}

Taking data from Scopus by using search keywords as "additive manufacturing" "Organ", a total of 196 articles reported in this specific area. In the year 2010, the first article on additive manufacturing in organ printing was published. In 2011 (3), 2012 (5), 2013 (6), 2014 (13), 2015 (22), 2016 (33), 2017 (34), 2018 (39) and in this year up to October 2019, total 39 research articles are published so far.

There are different sources and journal published research articles in this area. Here, we reported top-five journals, Biofabrication having maximum publications of 9. Materials (7), Annals of Biomedical Engineering (4), International Journal of Bioprinting (4) and Acta Biomaterialia journal published three research papers in this specific area. Other sources and journals were also having a good number of 
Table 5

Limitations when additive manufacturing is used for tissue and organ printing.

\begin{tabular}{|c|c|c|c|}
\hline S.No & Limitations & Description & References \\
\hline 1 & Lack of diversity in biomaterials & $\begin{array}{l}\text { - The main limitation of this technology is the lack of diversity in } \\
\text { biomaterials } \\
\text { - 3D printer having limited capabilities of speed and resolution depend } \\
\text { upon individual cases } \\
\text { - Biomaterial must be biocompatible, printable, possess good degradation } \\
\text { kinetics, appropriate mechanical properties, exhibits tissue bio-mimicry } \\
\text { and safe degradation }\end{array}$ & $\begin{array}{l}\text { Guvendiren et al., } 2016^{16} \text {; Przekora, } \\
2019^{100}\end{array}$ \\
\hline 2 & The requirement of mechanical strength & $\begin{array}{l}\text { - It does not provide suitable mechanical strength to the printed part } \\
\text { requires a complex combination of mechanical properties during the } \\
\text { regeneration process }\end{array}$ & $\begin{array}{l}\text { Shao and Fu, } 2013^{101} \text {; Tong et al., } \\
2015^{102}\end{array}$ \\
\hline 3 & Human Trails & $\begin{array}{l}\text { - Extensive Human trials are necessary before the actual implementation of } \\
\text { these tissue/organ in the patient body } \\
\text { - Sometimes it can be risky for the patient } \\
\text { - Different biomaterials are being developed and identified, but they have } \\
\text { limited ability and functionality }\end{array}$ & $\begin{array}{l}\text { Turnbull et al., } 2017^{103} \text {; Ottensmeyer } \\
\text { et al., } 2018^{104}\end{array}$ \\
\hline 4 & Availability of limited biomaterials & $\begin{array}{l}\text { - Limited biocompatible materials available for each type of 3D printing } \\
\text { technology } \\
\text { - There is a reasonable requirement for extensive research before } \\
\text { commercial production of biomaterials for the medical field }\end{array}$ & $\begin{array}{l}\text { Tallawi et al., } 2015^{105} \text {; Javaid and } \\
\text { Haleem, } 2016^{106}\end{array}$ \\
\hline 5 & Appropriate selection of biomaterial & $\begin{array}{l}\text { - Proper selection of biomaterial must be required for appropriate printing } \\
\text { of tissue and organ } \\
\text { - Biomaterials depend upon the condition of diseases; thus proper selection } \\
\text { is required }\end{array}$ & $\begin{array}{l}\text { Hasan et al., } 2016^{107} \text {; Madrigal et al., } \\
2017^{108}\end{array}$ \\
\hline 6 & Does not provide required cells & $\begin{array}{l}\text { - This technology cannot deliver the numbers of cells required for different } \\
\text { tissue/organs } \\
\text { - It does not create the uniaxial nervous network/branched vascular in a } \\
\text { construct }\end{array}$ & $\begin{array}{l}\text { Krishnan et al., } 2014^{109} \text {; Jiang et al., } \\
2016^{110} \text {; Kant and Coulombe, } 2018^{111}\end{array}$ \\
\hline 7 & Ethics & $\begin{array}{l}\text { - Need approval for the actual implementation of these 3D printed part for } \\
\text { the patient } \\
\text { - Must require authorisation whether it will be feasible or not } \\
\text { - Safety of the patient must be required during implementation } \\
\text { - Regularity approval required from concerned health authorities }\end{array}$ & $\begin{array}{l}\text { Diomede et al., } 2018^{112} \text {; Ebbing et al., } \\
2018^{113}\end{array}$ \\
\hline 8 & Limited polymers & $\begin{array}{l}\text { - It includes limited photocurable polymer resin and biodegradable } \\
\text { polymer for printing } \\
\text { - In tissue engineering, there are uneven approaches in scaffolds cell } \\
\text { seeding and face problem during incorporation of multiple cells }\end{array}$ & $\begin{array}{l}\text { Choi et al., } 2017^{114} \text {; Liu et al., } 2018^{115} \\
\text { González-Henríquez et al., } 2019^{116}\end{array}$ \\
\hline 9 & Damaging of cells & $\begin{array}{l}\text { - Shear force during rapid printing damages cells and create a dead core in } \\
\text { the thickness } \\
\text { - Sometimes, this creates a high risk for printed medical parts }\end{array}$ & $\begin{array}{l}\text { Jackson et al., } 2018^{117} \text {; Celikkin et al., } \\
2019^{118}\end{array}$ \\
\hline 10 & Standardisation & $\begin{array}{l}\text { - Evidence-based trials required for the best treatment and maintain } \\
\text { standardisation which takes extra time } \\
\text { - No standards regarding safety and quality to the concerned patient }\end{array}$ & $\begin{array}{l}\text { Phan et al., } 2016^{119} \text {; Lau and Sun, } \\
2018^{120} \text {; Javaid and Haleen, } 2019^{121}\end{array}$ \\
\hline 11 & Not readily accepted by the human body & $\begin{array}{l}\text { Due to introducing of new biomaterials for tissue and organs, many times } \\
\text { they do not have readable acceptability in the human body } \\
\text { - Requires very high level of research and development and the same is } \\
\text { costly } \\
\text { - Extensive testing of new biomaterial testing is very much required, and it } \\
\text { is quite costly }\end{array}$ & $\begin{array}{l}\text { Samorezov and Alsberg, } 2015^{122} \text {; Bose } \\
\text { et al., } 2018^{123} \text {; Javaid and Haleem, } \\
2019^{124}\end{array}$ \\
\hline 12 & Requirements of tissue for long term usage & $\begin{array}{l}\text { - There are limited hydrogels (used to make soft contact) which are } \\
\text { suitable for bioink } \\
\text { - These 3D printed tissue and organ do not survive for the long term in the } \\
\text { patient body }\end{array}$ & Song et al., $2018^{125}$; Qasim et al., $2019^{92}$ \\
\hline 13 & $\begin{array}{l}\text { Understanding of the relation between the } \\
\text { biomaterial properties and the printing } \\
\text { outcomes }\end{array}$ & $\begin{array}{l}\text { - Relatively poor understanding of the relation between the biomaterial } \\
\text { properties and the printing outcome } \\
\text { - Multilayered tissue engineering Scaffolds are new challenges } \\
\text { - Having limited computational power by which proper outcome does not } \\
\text { achieve using biomaterials }\end{array}$ & $\begin{array}{l}\text { Butscher et al., } 2013^{31} \text {; Gerstleet al., } \\
2014^{126} \text {; Zadpoor, } 2017^{127}\end{array}$ \\
\hline
\end{tabular}

publications in this emerging area.

In-country wise contribution on Additive manufacturing in organ printing, United States having maximum contribution of $28 \%$, China (8\%), Singapore (5\%), Italy (5\%), India (4\%), United Kingdom (4\%), Netherlands (4\%) and other counties also contributes $42 \%$.

In area wise contributions, "Engineering" field having a maximum contribution of $27 \%$. Materials Science (18\%), Biochemistry, Genetics and Molecular Biology (14\%), Medicine (10\%), Chemical Engineering (10\%), Computer Science (5\%), Physics and Astronomy (4\%) and other field contribute $12 \%$.

\subsection{Research status on $3 D$ printing in tissue}

Numbers of research papers are published on 3D printing in tissue. By searching keyword as "3D printing" "tissue" from Scopus, total 2701 research articles are published so far up to October 2019. The first articles on this specific field by implementation this technology was published in 1998 and after a gap of four years, the second article was published in 2002, and this year two articles were published. In 2003 (1), 2004 (2), 2005 (7), 2006 (6), 2007 (8), 2008 (8), 2009 (12), 2010 (13), 2011 (14), 2012 (16), 2013 (44), 2014 (130), 2015 (231), 2016 (372), 2017 (507), 2018 (664), and in 2019 till last day of October 657 articles are published. 
Different sources and journal published research articles in this field. Out these top five journals are Biofabrication (81), Acta Biomaterialia (59), Materials Science and Engineering C (52), Journal "ACS Applied Materials and Interfaces", and "Chinese Journal of Tissue Engineering Research" both having 51 research publications.

In country-wise contribution, United States having maximum contribution of $27 \%$, whereas China (17\%), United Kingdom (6\%), South Korea (6\%), Germany (5\%), Australia (4\%), Singapore (3\%) and other countries also have good contribution of $32 \%$ in this field.

In area wise contributions on 3D printing applications in tissue, "Engineering" field having a maximum contribution of $22 \%$. Materials Science contributes $21 \%$, Biochemistry, Genetics and Molecular Biology (13\%), Medicine (12\%), Chemical Engineering (8\%), Physics and Astronomy (6\%), Chemistry (5\%) and other fields having 13\% contributions.

\subsection{Research status on $3 D$ printing in organ}

By the search of keywords as "3D printing" "organ" from Scopus, a total of 568 research articles are published so far up to October 2019. The first research articles on this specific field were published in 2006, and in this year, two articles were published. In 2007, no article was published. In 2008 (2), 2009 (2), 2010 (2), 2011 (3) and again, no research article was published in the year 2012. In the year 2013 (16), 2014 (27), 2015 (52), 2016 (107), 2017 (105), 2018 (134), and so far 116 research articles are published in this year in 2019.

Different sources and journals published articles on 3D printing applications in organ printing. In top five journals, "Biofabrication" journal publishes 12 research articles, Advanced Healthcare Materials having publications of 10 articles, Progress in Biomedical optics and imaging proceedings of SPIE and Scientific Reports have an equal number of publications of 8 research articles, Artificial Organs published seven articles. Various other journals also have a significant contribution to publication in this specific field.

In country-wise contribution, United States has a maximum contribution of $24 \%$, whereas China (15\%), South Korea (8\%), Germany (5\%), United Kingdom (5\%), Japan (4\%), Singapore (4\%) and other countries also have $35 \%$ contribution.

In area wise contribution Engineering field having maximum contribution of $22 \%$ and material science (16\%), Medicine (15\%), Biochemistry, Genetics and Molecular Biology (11\%), Chemical Engineering (8\%), Physics and Astronomy (5\%), Computer Science (5\%) and other field having $16 \%$ contribution.

Therefore, from Scopus data, it has been identified that the applications of this technology emerge in this specific field of medical. Further, in this section, we analysed that there are a large number of papers being published in the area of tissue and organ. This technology assists and provides direction to researchers.

\section{Main components of additive manufacturing for tissue and organ printing}

Additive manufacturing can undertake quick scaling and has excellent flexibility of the material. It uses almost all types of material depending upon the requirements and the available technologies. It can also scale design as per cost to size ratio. The process of tissue and organ printing start with biomaterials which meet different needs like bioactivity, biodegradability, shape, size, porosity etc. 3D printing has revolutionized the healthcare for the manufacturing of patient-specific complex implants and prosthetic. Biomaterials support the survival of a cell for the required function in the patient body. ${ }^{18,19}$ These biomaterials have cell adhesion capability using three strategies physical modification, chemical modification, and surface coatings having better interaction. Table 1 provides a list of critical components of additive manufacturing useable for tissue and organ printing.

Scientist and researcher are developing and commercialising AM technology to produce a realistic structure. As, it seems a useful tool for tissue engineering to help create a structure with required shape, strength, volume, that easily resemble natural tissue. It prints different materials, and during the printing process, it keeps cells alive. It can maintain the mechanical properties of the medical part by using innovative materials. This technology is used for the replacement of infarcted cardiac tissues and regeneration of progenitor cells. It efficiently produces artificial organs, tissue and implants to fulfil the requirement.

\section{Processes used to create tissue/organ using additive manufacturing}

Magnetic Resonance Imaging (MRI) and Computed Tomography (CT) is a useful technique to design and develop patient-specific parts. 3D printing can fabricate required functional organ and tissue with biomaterials and multiple cells. ${ }^{34,35}$ These biomaterials have excellent biological, chemical and mechanical properties. There are different materials which have bone-like properties and are used in 3D printing. These materials include silica, graphene, zirconium oxide, and bio glass. Processes used to create tissue/organ using AM are discussed in Table 2.

$3 \mathrm{D}$ data play an essential role in the design and development of customised 3D implants obtained from MRI and CT. This technique easily captures the organ, bone and tissue to make further development without any harmful effect. Medical image captured by these scanning technologies is saved further in Digital Imaging and Communication in Medicine (DICOM) format. This file is converted into a 3D CAD file and exported in STL format in 3D printing technologies. Finally, the printed model is implemented in the body of the patient to fulfil the desired requirement. $^{52}$

\section{Different requirements of materials for tissue and organ printing}

Biomaterials support cell function and proliferation while introducing cell in the scaffolds. AM is an innovative technique for scaffold fabrication for tissue. This technology has various advantages over conventional method such as multi-material printing, complex geometries manufacturing in lesser time and cost. A few researchers and scientists have created tissue with multiple cells. Table 3 provides different requirements for materials to be employed for tissue and organ printing.

Researchers have used this technology for congenital heart problems and diagnosis of heart diseases. Biomaterials model printed by this technology is precisely used to compare surgical finding with an actual demonstration. It increases the confidence level of the surgeon, which is not possible with different medical scanning technique. Further, this technology is used as advance medical education and learning about the cause and impact of various diseases. Surgeon and patient can now better understand the surgical treatment and diseases. $^{66}$

\section{Different advancement of additive manufacturing in the medical field}

The personalized reconstructed of tissue engineering scaffold is done using data from medical CT/MRI scan. There are different materials used for the precise development of a scaffold, tissue, organs, and other medical parts. AM bio-printing is used to rebuild the damaged organ of the various region of the body. This technology can print muscle, organ, cartilage, bone and skin tissue. ${ }^{67,68}$ AM significantly contributes to advancement in tissue engineering with the help of innovative biomaterials. Table 4 discusses different advancement of additive manufacturing in the medical field.

One of the major organs for transplant for a patient is liver and kidney, which are being experimented using AM technology. Polymers 
also are used in AM technologies for a few types of tissues, which are helpful in transplantation. ${ }^{97-99}$ One of the significant challenges in tissue engineering is the research \& development on different types of tissue, and another is the fabrication of complex tissue which can adequately be taken up by this technology.

\section{Limitation of additive manufacturing for tissue and organ printing}

There are different limitations of additive manufacturing for the printing of tissue/organ. Due to low mechanical strength and properties of available biomaterials, it does not print appropriate tissue and organs which can directly implement in the human body. Table 5 shows, different limitations of additive manufacturing for tissue and organ printing.

Additive manufacturing does not provide the capability to deliver the required numbers of cells required for different tissue. It includes limited photocurable polymer resin and biodegradable polymer for printing during incorporation of multiple cells. These limitations will be developed by new biomaterials and AM technology to make advancement in the medical field. There is a requirement of effect health, ${ }^{128}$ so this technology is implemented in the medical field to address required problem. ${ }^{129-131}$

\section{Discussion}

Additive manufacturing rapidly embraced in medical field, as it provides freedom of design and material for printing of tissue, organs and cells. It fabricates hydrogel structure by incorporation of cells. This is an innovative technology which can convert a digital design into physical objects. There is vast research going on tissue engineering for the replacement of tissue and organ. Biomaterial fabricated scaffold plays a vital role during the replacement of human tissue and organ. These biomaterials are used in skin, bone, cartilage, vessel, tendons, bladder, tissue, nerves and liver. There are different polymers like chondroitin sulphate, collagen and chitosan used for biomedical applications. Bone is one of the parts widely used in daily life. During any trauma or disease, bone can quickly regenerate by using AM technology. It enhances bone regeneration defect and bone tissue engineering. Currently, bioactive inorganic materials and composites of polymers are developing to increase the mechanical stability of scaffold and tissue interaction.

Biocompatible materials are necessary to create a scaffold, which helps cells to perform routine functions. Additive manufacturing helps in biocompatible printing materials as per the required shape and size. Implants printed by these materials have much better efficiency and lesser reaction after implantation in the patient body. A customised, cost-effective scaffold for bone tissue engineering is possible with AM. Further with this advancement, a wide variety of bimetallic, bioceramics, biopolymers, and biocomposites materials are now available for meeting challenges, and these materials are more suitable for cell adhesion and growth for tissue and organs. This technology is suitable for tissue engineering of complex structure to meet the personalized medical requirement. It can incorporate cells, proteins to form excellent biological properties. This technology quickly constructs scaffolds by which living cells are grown. The regeneration of damaged tissue is done quickly and repairs the body without any problem/side effect.

\section{Future scope}

In future, $\mathrm{AM}$ will enhance its potential for personalized tissue engineering. It will bring significant advancement in diagnostics and therapeutics. AM meets the future demand of tissue, organs and vascular structure as per patient demand. It shows great interest in the design and development of an artificial heart with the help of biomaterials. In upcoming years, the medical profession will explore this technology to print microchannels, which can be used to maximize the amount of oxygen and nutrients from neighbouring tissues. AM may change the way of the manufacturing of tissue, organs and other devices if used as per the patient's requirements. With proper research \& development, it is to provide confidence to doctors, surgeon, researcher and medical practitioner in this essential area to save humanity. In future, there is a possibility to use this technology to seed neuronal cells, which will be helpful to repair spinal cord and brain injury.

\section{Conclusion}

Additive manufacturing is used to print biomaterial and provides efficient technologies to combine cell and improve their growth factor. By 3D printing, biomaterial can be added layer by layer and to form tissue-like structure. This can easily print tissue, cell and organ, which help to regenerate joints and ligaments. Liquefied material which provides oxygen and nutrients for alive is mixed with the cells. This mixing of cells, nutrients and matrix is known as bioink. It is placed in the head of the 3D printer, and layers are deposited as per the data of patient captured by CT and MRI. It is a biological construct of cells and constructs of artificial organs like kidney, liver and other working blood vessels. After printing, it is necessary to create the growth of tissues and the ability to survive transplants. This technology is now being used as an innovative approach of autonomous self-assembly, biomimicry, and to fabricate mini-tissue building blocks. Researchers are focus to develop living organs having excellent biological and mechanical properties using 3D printing. The main goal of this technology is to create a structure like natural, which can be survived in the human body. It quickly creates a cellular part of the organs having self-assembly approaches.

\section{Declaration of competing interest}

None.

\section{References}

1. Javaid M, Haleem A. Additive manufacturing applications in medical cases: a literature-based review. Alexandria J Med. 2018;54(4):411-422.

2. Martinez-Marquez D, Mirnajafizadeh A, Carty CP, Stewart RA. Application of quality by design for 3D printed bone prostheses and scaffolds. PLoS One. 2018;13(4):e0195291https://doi.org/10.1371/journal.pone.0195291.

3. Aimar A, Palermo A, Innocenti B. The role of 3D printing in medical applications: a state of the art. J Healthc Eng. 2019. https://doi.org/10.1155/2019/5340616.

4. Melchels FP, Domingos MA, Klein TJ, Malda J, BartoloPJ HutmacherDW. Additive manufacturing of tissues and organs. Prog Polym Sci. 2012;37:1079-1104.

5. Van Duinen V, TrietschSJ, Joore J, Vulto P, Hankemeier T. Microfluidic 3D cell culture: from tools to tissue models. Curr Opin Biotechnol. 2015;35:118-126.

6. Haleem A, Javaid M. Polyether ether ketone (PEEK) and its manufacturing of customised 3D printed dentistry parts using additive manufacturing. Clin Epidemiol Global Health. 2019. https://doi.org/10.1016/j.cegh.2019.03.001.

7. Wang $\mathrm{X}$, Ao $\mathrm{Q}$, Tian $\mathrm{X}$, et al. 3D bioprinting technologies for hard tissue and organ engineering. Materials. 2016;9(10):802. https://doi.org/10.3390/ma9100802.

8. Domenech M, Polo-Corrales L, Ramirez-Vick JE, Freytes DO. Tissue engineering strategies for myocardial regeneration: acellular versus cellular scaffolds? Tissue Eng B Rev. 2016;22(6):438-458.

9. Horn TJ, Harrysson OLA. Overview of current additive manufacturing technologies and selected applications. Sci Prog. 2012;95(3):255-282.

10. Rosenzweig DH, Carelli E, Steffen T, Jarzem P, Haglund L. 3D-Printed ABS and PLA scaffolds for cartilage and nucleus pulposus tissue regeneration. Int J Mol Sci. 2015;16(7):15118-15135

11. Javaid M, Haleem A. Current status and applications of additive manufacturing in dentistry: a literature-based review. J Oral Biol Craniofac Res. 2019;9:179-185.

12. KalitaSJ Bose S, Hosick HL, Bandyopadhyay A. Development of controlled porosity polymer-ceramic composite scaffolds via fused deposition modelling. Mater Sci Eng C. 2003;23(5):611-620.

13. Schuurman W, Levett PA, Pot MW, et al. Gelatin-methacrylamide hydrogels as potential biomaterials for fabrication of tissue-engineered cartilage constructs. Macromol Biosci. 2013;13:551-561.

14. Haleem A, Javaid M, Saxena A. Additive manufacturing applications in cardiology: a review. Egypt Heart J. 2018;70(4):433-441.

15. Chang R, Emami K, Wu H, Sun W. Biofabrication of a three-dimensional liver microorgan as an in vitro drug metabolism model. Biofabrication. 2010;2(4) 045004.

16. Guvendiren M, Molde J, Soares RM, Kohn J. Designing biomaterials for 3D printing. 
ACS Biomater Sci Eng. 2016;2(10):1679-1693.

17. Choi YJ, Park JH, Jang J, Cho DW. 3D bioprinting technologies and bioinks for therapeutic and tissue engineering applications. J 3D Print Med. 2018. https://doi. org/10.2217/3dp-2018-0014

18. Sears NA, SeshadriD R, Dhavalikar PS, Cosgriff-Hernandez E. A review of threedimensional printing in tissue engineering. Tissue Eng B. 2016;22:2 98-310.

19. Zhu W, Qu X, Zhu J, et al. Direct 3D bioprinting of prevascularized tissue constructs with complex microarchitecture. Biomaterials. 2017;124:106-115.

20. Derby B. Printing and prototyping of tissues and scaffolds. Science. 2012;338:921-926.

21. Bose S, Vahabzadeh S, Bandyopadhyay A. Bone tissue engineering using 3D printing. Mater Today. 2013;16:496-504.

22. Singh D, Singh D, Han SS. 3D printing of scaffold for cells delivery: advances in skin tissue engineering. Polymers. 2016;8(1):19.

23. Maiullari F, Costantini M, Milan M, et al. A multi-cellular 3D bioprinting approach for vascularized heart tissue engineering based on HUVECs and iPSC-derived cardiomyocytes. Sci Rep. 2018;8(1):1-15.

24. Gómez-Ciriza G, Hussain T, Gómez-Cía T, Valverde I. Potential of 3D-printed models in planning structural interventional procedures. Interv Cardiol. 2015;7:1-5.

25. Pati F, Cho DW. Bioprinting of 3D tissue models using decellularized extracellular matrix bioink. Methods Mol Biol. 2017;1612:381-390.

26. Laschke MW, Menger MD. Life is 3d: boosting spheroid function for tissue engineering. Trends Biotechnol. 2017;35(2):133-144.

27. Haleem A, Javaid M. 3D scanning applications in medical field: a literature-based review. Clin Epidemiol Global Health. 2019;7(2):199-210.

28. Stanton MM, Samitier J, Sanchez S. Bioprinting of 3D hydrogels. Lab Chip. 2015;15(15):3111-3115.

29. Ligon SC, Liska R, Stampfl J, Gurr M, Mülhaupt R. Polymers for 3D printing and customized additive manufacturing. Chem Rev. 2017;117(15):10212-10290. https://doi.org/10.1021/acs.chemrev.7b00074.

30. Ong CS, Fukunishi T, Zhang H, et al. Biomaterial-free three-dimensional bioprinting of cardiac tissue using human induced pluripotent stem cell-derived cardiomyocytes. Sci Rep. 2017;7(1):4566.

31. Butscher A, Bohner M, Doebelin N, Hofmann S, Muller R. New depowderingfriendly designs for three-dimensional printing of calcium phosphate bone substitutes. Acta Biomater. 2013;9(11):9149-9158.

32. Usprech J, Romero DA, Amon $\mathrm{CH}$, Simmons CA. Combinatorial screening of 3D biomaterial properties that promote myofibrillogenesis for mesenchymal stromal cell-based heart valve tissue engineering. Acta Biomater. 2017;58:34-43.

33. Jammalamadaka U, Tappa $\mathrm{K}$. Recent advances in biomaterials for $3 \mathrm{D}$ printing and tissue engineering. J Funct Biomater. 2018;9(1):22. https://doi.org/10.3390/ jfb9010022.

34. Negi S, Dhiman S, Sharma RK. Basics and applications of rapid prototyping medical models. Rapid Prototyp J. 2014;20:256-267.

35. Haleem A, Javaid M. Polyether ether ketone (PEEK) and its 3D printed implants applications in the medical field: an overview. Clin Epidemiol Global Health. 2019. https://doi.org/10.1016/j.cegh.2019.01.003.

36. YooSJ, Lo Rito M, Seed M, Grosse-Wortmann L. Magnetic resonance imaging as a decision-making tool in congenital heart disease surgery. Oper Tech Thorac Cardiovasc Surg. 2014;19:152-163.

37. Ripley B, Kelil T, Cheezum MK, et al. 3D printing based on cardiac CT assists anatomic visualization before transcatheter aortic valve replacement. $J$ Cardiovasc Comput Tomogr. 2016;10(1):28-36.

38. Ackland DC, Robinson D, Redhead M, Vee Sin Lee P, Moskaljuk A, Dimitoulis GA. Personalized 3D-printed prosthetic joint replacement for the human temporomandibular joint: from implant design to implantation. J Mech Behav Biomed Mater. 2017;69:404-411.

39. Schieker M, Seitz H, Drosse I, Seitz S, Mutschler W. Biomaterials as scaffold for bone tissue engineering. Eur J Trauma. 2006;32:114-124.

40. Tappa K, Jammalamadaka U. Novel biomaterials used in medical 3D printing techniques. J Funct Biomater. 2018;9(1):17. https://doi.org/10.3390/jfb9010017.

41. Yang SF, Yang HY, Chi XP, et al. Rapid prototyping of ceramic lattices for hard tissue scaffolds. Mater Eng. 2008;29(9):1802-1809.

42. Do A-V, Khorsand B, Geary SM, Salem AK. 3D printing of scaffolds for tissue regeneration applications. Adv Healthc Mater. 2015;4(12):1742-1762.

43. O'Brien CM, Holmes B, Faucett S, Zhang LG. Three-dimensional printing of nanomaterial scaffolds for complex tissue regeneration. Tissue Eng B Rev. 2015;21(1):103-114.

44. An J, Teoh JEM, Suntornnond R, Chua CK. Design and 3D printing of scaffolds and tissues. Engineering. 2015;1(2):261-268.

45. Qiu K, Haghiashtiani G, McAlpine MC. 3D printed organ models for surgical applications. Annu Rev Anal Chem. 2018;11(1):287-306.

46. Bertassoni LE, Cardoso JC, Manoharan V, et al. Direct-write bioprinting of cell-laden methacrylatedgelatin hydrogels. Biofabrication. 2014;6(2) 024105.

47. Csobonyeiova M, Polak S, Koller J, Danisovic L. Induced pluripotent stem cells and their implication for regenerative medicine. Cell Tissue Bank. 2015;16(2):171-180.

48. Gao L, Kupfer ME, Jung JP, et al. Myocardial tissue engineering with cells derived from human-induced pluripotent stem cells and a native-like, high-resolution, 3dimensionally printed scaffold. Circ Res. 2017;120(8):1318-1325.

49. Li X, Cui R, Sun L, et al. 3D-Printed biopolymers for tissue engineering application. Int J Polym Sci. 2014. https://doi.org/10.1155/2014/829145.

50. Bishop ES, Mostafa S, Pakvasa M, et al. 3-D bioprinting technologies in tissue engineering and regenerative medicine: current and future trends. Genes Dis. 2017;4(4):185-195.

51. Kiraly L, Khalifa S. Three-dimensional modelling and three-dimensional printing in pediatric and congenital cardiac surgery. Transl Pediatr. 2018;7(2):129-138.
52. Haleem A, Javaid M. Role of CT and MRI in the design and development of orthopaedic model using additive manufacturing. J Clin Orthop Trauma. 2018;9(3):213-217.

53. Wang H, Li Y, Zuo Y, Li J, Ma S, Cheng L. Biocompatibility and osteogenesis of biomimetic nano-hydroxyapatite/polyamide composite scaffolds for bone tissue engineering. Biomaterials. 2007;28(22):3338-3348.

54. Zhang JH, Zhao SC, Zhu YF, et al. Three-dimensional printing of strontium-containing mesoporous bioactive glass scaffolds for bone regeneration. Acta Biomater. 2014;10(5):2269-2281.

55. Luo YX, Zhai D, Huan ZG, et al. Three-Dimensional printing of hollow-struts-packed bioceramic scaffolds for bone regeneration. ACS Appl Mater Interfaces. 2015;7(43):24377-24383

56. Zhang B, Montgomery M, Chamberlain MD, et al. Biodegradable scaffold with built in vasculature for organ-on-a-chip engineering and direct surgical anastomosis. Nat Mater. 2016;15(6):669.

57. Wang K, Wu C, Qian Z, Zhang C, Wang B, Vannan MA. Dual-material 3D printed metamaterials with tunable mechanical properties for patient-specific tissue-mimicking phantoms. Addit Manuf. 2016;12:31-37

58. Mironov AV, Grigoryev AM, Krotova LI, et al. 3D printing of PLGA scaffolds for tissue engineering. J Biomed Mater Res A. 2017;105(1):104-109.

59. Hangge P, Pershad Y, Witting AA, Albadawi H, Oklu R. Three-dimensional (3D) printing and its applications for aortic diseases. Cardiovasc Diagn Ther 2018;8(1):19-25.

60. Seitz H, Rieder W, Irsen S, Leukers B, Tille C. Three-dimensional printing of porous ceramic scaffolds for bone tissue engineering. J Biomed Mater Res B Appl Biomater 2005;74:782-788.

61. Lee SH, Zhou WY, Wang M, Cheung WL, Ip WY. Selective laser sintering of poly(LLactide) porous scaffolds for bone tissue engineering. $J$ Biomimetics, Biomaterials Tissue Eng. 2008;1 81-8910.4028 www.scientific.net/JBBTE.1.81.

62. Zhou WY, Lee SH, Wang M, Cheung WL, Ip WY. Selective laser sintering of porous tissue engineering scaffolds from poly(L-Lactide)/carbonated hydroxyapatite nanocomposite microspheres. J Mater Sci Mater Med. 2008;19:2535-2540. https://doi. org/10.1007/s10856-007-3089-3.

63. Cohen DL, Lipton JI, Bonassar LJ, Lipson H. Additive manufacturing for in situ repair of osteochondral defects. Biofabrication. 2010;2(3):035004.

64. Bergmann C, Lindner M, Zhang W, et al. 3D printing of bone substitute implants using calcium phosphate and bioactive glasses. $J$ Eur Ceram Soc. 2010;30(12):2563-2567.

65. Kang HW, Lee SJ, Ko IK, et al. A 3D bioprinting system to produce human-scale tissue constructs with structural integrity. Nat Biotechnol. 2016;34(3):312-319.

66. Javaid M, Haleem A, Kumar L. Current status and applications of 3D scanning in dentistry. Clin Epidemiol Global Health. 2019;7(2):179-185.

67. Saunders RE, Derby B. Inkjet printing biomaterials for tissue engineering: bioprinting. Int Mater Rev. 2014;59(8):430-448.

68. Zheng Y, Wang Y, Chen RK, et al. Tissue transformation mould design and stereolithography fabrication. Rapid Prototyp J. 2017;23(1):162-168.

69. Murphy SV, Atala A. 3D bioprinting of tissues and organs. Nat Biotechnol 2014;32(8):773-785.

70. Knowlton S, Yenilmez B, Tasoglu S. Towards single-step -bio-fabrication of organs on a chip via 3D printing. Trends Biotechnol. 2016;34(9):685-688.

71. Ji S, Guvendiren M. Recent advances in bioink design for 3D bioprinting of tissue and organs. Front Bioeng Biotechnol. 2017;5(5):23. https://doi.org/10.3389/fbioe. 2017.00023.

72. Capel AJ, Rimington RP, Fleming JW, et al. Scalable 3D printed molds for human tissue engineered skeletal muscle. Front Bioeng Biotechnol. 2019;7:20. https://doi. org/10.3389/fbioe.2019.00020.

73. Cai H, Azangwe G, Shepherd DET. Skin cell culture on an ear-shaped scaffold created by fused deposition modelling. Bio Med Mater Eng. 2005;15(5):375-380.

74. Huh D, Hamilton GA, Ingber DE. From 3D cell culture to organs-on-chips. Trends Cell Biol. 2011;21(12):745-754.

75. Kolesky DB, Truby RL, Gladman AS, Busbee TA, Homan KA, Lewis JA. 3D bioprinting of vascularized, heterogeneous cell-laden tissue constructs. Adv Mater 2014;26(19):3124-3130

76. Zhao Y, Yao R, Ouyang L, et al. Three-dimensional printing of Hela cells for cervical tumour model in vitro. Biofabrication. 2014;6(3) 035001.

77. Jang J, Park HJ, Kim SW, et al. 3D printed complex tissue construct using stem cell laden decellularized extracellular matrix bioinks for cardiac repair. Biomaterials. 2017; 112:264-274

78. Costello JP, Olivieri RJ, Su L, et al. Incorporating three-dimensional printing into a simulation-based congenital heart disease and critical care training curriculum for resident physicians. Congenit Heart Dis. 2015;10(2):185-190.

79. Kolesky DB, Homan KA, Skylar-Scott MA, Lewis JA. Three-dimensional bioprinting of thick vascularized tissues. Proc Natl Acad Sci U S A. 2016;113(12):3179-3184.

80. Lau I, Sun Z. Three-dimensional printing in congenital heart disease: a systematic review. J Med Radiat Sci. 2018;65(3):226-236.

81. Lee V, Singh G, Trasatti JP, et al. Design and fabrication of human skin by threedimensional bioprinting. Tissue Eng Part C. 2014;20(6):473-484.

82. Takahashi H, Okano T. Cell sheet-based tissue engineering for organizing anisotropic tissue constructs produced using microfabricated thermoresponsive substrates. Adv Healthc Mater. 2015;4(16):2388-2407.

83. Xiong Z, Yan Y, Wang S, Zhang R, Zhang C. Fabrication of porous scaffolds for bone tissue engineering via low-temperature deposition. Scr Mater. 2002;46:771-776.

84. Leukers B, Gülkan H, Irsen S, et al. Hydroxyapatite scaffolds for bone tissue engineering made by 3D printing. J Mater Sci Mater Med. 2005;16:1121-1124. https:// doi.org/10.1007/s10856-005-4716-5.

85. Mota RCAG, Silva EO, Lima FF, Menezes LR, Thiele ACS. 3D printed scaffolds as a 
new perspective for bone tissue regeneration: literature review. Mater Sci Appl. 2016;7(8):430-452.

86. Miao S, Castro N, Nowicki M, et al. 4D printing of polymeric materials for tissue and organ regeneration. Mater Today. 2017;20(10):577-591. https://doi.org/10.1016/j. mattod.2017.06.005.

87. Javaid M, Haleem A. 4D printing applications in medical field: a brief review. Clin Epidemiol Global Health. 2018. https://doi.org/10.1016/j.cegh.2018.09.007.

88. Piedade AP. 4D printing: the shape-morphing in additive manufacturing. $J$ Funct Biomater. 2019;10(1):9. https://doi.org/10.3390/jfb10010009.

89. Bodaghi M, Noroozi R, Zolfagharian A, Fotouhi M, Norouzi S. 4D printing selfmorphing structures. Materials. 2019;12(8):1353. https://doi.org/10.3390/ ma12081353.

90. Giannopoulos AA, Steigner ML, George E, et al. Cardiothoracic applications of 3dimensional printing. J Thorac Imaging. 2016;31(5):253-272.

91. YooSJ Thabit $\mathrm{O}$, Kim EK, Ide H, et al. 3D printing in medicine of congenital heart diseases. 3D Print Med. 2016;2(1):3. https://doi.org/10.1186/s41205-016-0004-x.

92. Qasim M, Haq F, Kang MH, Kim JH. 3D printing approaches for cardiac tissue engineering and role of immune modulation in tissue regeneration. Int J Nanomed. 2019; 14:1311-1333.

93. Will J, Melcher R, Treul C, et al. Porous ceramic bone scaffolds for vascularized bone tissue regeneration. J Mater Sci Mater Med. 2008;19(8):2781-2790.

94. Zhou Y. The recent development and applications of fluidic channels by 3D printing. J Biomed Sci. 2017;24(1):80. https://doi.org/10.1186/s12929-017-0384-2.

95. Datta P, Ayan B, Ozbolat IT. Bioprinting for vascular and vascularized tissue biofabrication. Acta Biomater. 2017;51:1-20.

96. Javaid M, Haleem A. Industry 4.0 applications in medical field: a brief review. Curr Med Res Pract. 2019. https://doi.org/10.1016/j.cmrp.2019.04.001.

97. Hsieh FY, Lin HH, Hsu SH. 3D bioprinting of neural stern cell-laden thermoresponsive biodegradable polyurethane hydrogel and potential in central nervous system repair. Biomaterials. 2015;71:48-57.

98. Muller M, Becher J, Schnabelrauch M, Zenobi-Wong M. Nanostructured Pluronic hydrogels as bioinks for 3D bioprinting. Biofabrication. 2015;7(3) 035006.

99. Shin SR, Li YC, Jang HL, et al. Graphene-based materials for tissue engineering. Adv Drug Deliv Rev, 2016;105(Pt B):255-274.

100. Przekora A. Current trends in fabrication of biomaterials for bone and cartilage regeneration: materials modifications and biophysical stimulations. Int J Mol Sci. 2019;20(2):435. https://doi.org/10.3390/ijms20020435.

101. Shao $\mathrm{Y}, \mathrm{Fu}$ J. Integrated micro/nanoengineered functional biomaterials for cell mechanics and mechanobiology: a materials perspective. Adv Mater. 2014;26(10):1494-1533

102. Tong Z, Solanki A, Hamilos A, et al. Application of biomaterials to advance induced pluripotent stem cell research and therapy. EMBO J. 2015;34(8):987-1008.

103. Turnbull G, Clarke J, Picard F, et al. 3D bioactive composite scaffolds for bone tissue engineering. Bioact Mater. 2017;3(3):278-314.

104. Ottensmeyer PF, Witzler M, Schulze M, Tobiasch E. Small molecules enhance scaffold-based bone grafts via purinergic receptor signaling in stem cells. Int $J \mathrm{Mol}$ Sci. 2018;19(11):3601. https://doi.org/10.3390/ijms19113601.

105. Tallawi M, Rosellini E, Barbani N, et al. Strategies for the chemical and biological functionalization of scaffolds for cardiac tissue engineering: a review. $J R S O c$ Interface. 2015;12(108):20150254. https://doi.org/10.1098/rsif.2015.0254.

106. Javaid M, Haleem A. Additive manufacturing applications in orthopaedics: a review. J Clin Orthop Trauma. 2018;9(3):202-206

107. Hasan A, Waters R, Roula B, et al. Engineered biomaterials to enhance stem cellbased cardiac tissue engineering and therapy. Macromol Biosci. 2016;16(7):958-977

108. Madrigal JL, Stilhano R, Silva EA. Biomaterial-guided gene delivery for musculoskeletal tissue repair. Tissue Eng B Rev. 2017;23(4):347-361.

109. Krishnan R, Alexander M, Robles L, Foster 3rd CE, Lakey JR. Islet and stem cell encapsulation for clinical transplantation. Rev Diabet Stud. 2014;11(1):84-101.

110. Jiang W, Li M, Chen Z, Leong KW. Cell-laden microfluidic microgels for tissue regeneration. Lab Chip. 2016;16(23):4482-4506

111. Kant RJ, CoulombeKLK. Integrated approaches to spatiotemporally directing angiogenesis in host and engineered tissues. Acta Biomater. 2018;69:42-62.

112. Diomede F, Gugliandolo A, Cardelli P, et al. Three-dimensional printed PLA scaffold and human gingival stem cell-derived extracellular vesicles: a new tool for bone defect repair. Stem Cell Res Ther. 2018;9(1):104. https://doi.org/10.1186/s13287018-0850-0.

113. Ebbing J, Jäderling F, Collins JW, et al. Comparison of 3D printed prostate models with standard radiological information to aid understanding of the precise location of prostate cancer: a construct validation study. PLoS One. 2018;13(6):e0199477.

114. Choi YJ, Yi HG, Kim SW, Cho DW. 3D cell printed tissue analogues: a new platform for theranostics. Theranostics. 2017;7(12):3118-3137.

115. Liu F, Chen Q, Liu C, et al. Natural polymers for organ 3D bioprinting. Polymers. 2018;10(11):1278. https://doi.org/10.3390/polym10111278.

116. González-Henríquez CM, Sarabia-Vallejos MA, Rodríguez Hernandez J. Antimicrobial polymers for additive manufacturing. Int J Mol Sci. 2019;20(5):1210. https://doi.org/10.3390/ijms20051210.

117. Jackson RJ, Patrick PS, Page K, et al. Chemically treated 3D printed polymer scaffolds for biomineral formation. ACS Omega. 2018;3(4):4342-4351.

118. Celikkin N, Mastrogiacomo S, WalboomersXF Swieszkowski W. Enhancing X-ray attenuation of 3D printed gelatin methacrylate (GelMA) hydrogels utilizing gold nanoparticles for bone tissue engineering applications. Polymers. 2019;11(2):367. https://doi.org/10.3390/polym11020367.

119. Phan K, Sgro A, Maharaj MM, D'Urso P, Mobbs RJ. Application of a 3D custom printed patient specific spinal implant for C1/2 arthrodesis. J Spine Surg. 2016;2(4):314-318

120. Lau IWW, Liu D, Xu L, Fan Z, Sun Z. Clinical value of patient-specific three-dimensional printing of congenital heart disease: quantitative and qualitative assessments. PLoS One. 2018;13(3):e0194333https://doi.org/10.1371/journal.pone. 0194333.

121. Javaid M, Haleem A. Using additive manufacturing applications for design and development of food and agricultural equipments. Int J Mater Prod Technol. 2019;58(2/3):225-238

122. Samorezov JE, Alsberg E. Spatial regulation of controlled bioactive factor delivery for bone tissue engineering. Adv Drug Deliv Rev. 2015;84:45-67.

123. Bose S, Robertson SF, Bandyopadhyay A. Surface modification of biomaterials and biomedical devices using additive manufacturing. Acta Biomater. 2018;66:6-22.

124. Javaid M, Haleem A. Current status and challenges of Additive manufacturing in orthopaedics: an overview. J Clin Orthop Trauma. 2019;10(2):380-386.

125. Song R, Murphy M, Li C, Ting K, Soo C, Zheng Z. Current development of biodegradable polymeric materials for biomedical applications. Drug Des Dev Ther. 2018;12:3117-3145.

126. Gerstle TL, Ibrahim AM, Kim PS, Lee BT, Lin SJ. A plastic surgery application in evolution: three-dimensional printing. Plast Reconstr Surg. 2014;133(2):446-451.

127. Zadpoor AA. Biomaterials and tissue biomechanics: a match made in heaven? Materials. 2017;10(5):528. https://doi.org/10.3390/ma10050528.

128. Awasthi S, Verma T, Agarwal M, Singh JV, Srivastava NM, Nichterd M. Developing effective health communication messages for community-acquired pneumonia in children under five years of age: a rural North Indian qualitative study. Clin Epidemiol Global Health. 2017;5:107-116.

129. Javaid M, Haleem A. 3D printed medical parts with different materials using additive manufacturing. Clin Epidemiol Global Health. 2019. https://doi.org/10.1016/ j.cegh.2019.08.002.

130. Chadha A, Haq MI, Raina A, Singh R, Penumarti N, Bishnoi M. Effect of fused deposition modelling process parameters on mechanical properties of 3D printed parts. World J Eng. 2019. https://doi.org/10.1108/WJE-09-2018-0329.

131. Jamróz W, Szafraniec J, Kurek M, Jachowicz R. 3D printing in pharmaceutical and medical applications - recent achievements and challenges. Pharm Res. 2018;35(9):176. https://doi.org/10.1007/s11095-018-2454-x. 